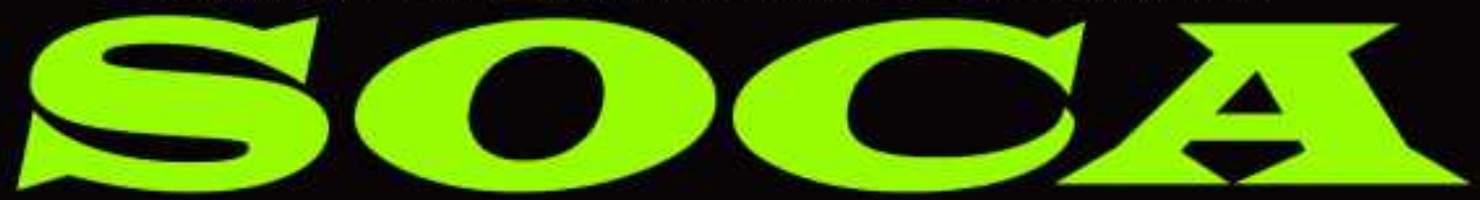

JOURNAL ON SOCIAL ECONOMICS OF AGRICULTURE

Vol.13 No.2 31 Agustus 2019

e-ISSN: $2615-6628$

p-ISSN: $1411-7176$

\title{
SISTEM PETERNAKAN SAPI DI PULAU SUMBAWA: PELUANG DAN HAMBATAN UNTUK PENINGKATAN PRODUKTIVITAS DAN PENDAPATAN PETANI DI LAHAN KERING
}

\author{
Nurul Hilmiati \\ Balai Pengkajian Teknologi Pertanian Nusa Tenggara Barat, Jalan Raya Peninjauan \\ Narmada Lombok Barat, Nusa Tengga Barat \\ Email: hilmiati@yahoo.com \\ Telp/HP: 081337332348
}

\begin{abstract}
ABSTRAK
Pulau Sumbawa merupakan salah satu sumber sapi nasional dimana petani umumnya menerapkan system integrasi tanaman pakan - ternak sebagai sumber pendapatan.Produktivitas sapi yang rendah di wilayah ini sudah tercatat dalam beberapa studi.Tulisan ini bertujuan untuk mengeksplorasi peluang dan tantangan untuk meningkatkan produktivitas sapi di wilayah Sumbawa yang beriklim kering dengan melihat berbagai system pemeliharaan yang sudah ada.Sebuah studi kasus telah dilaksanakan di Kabupaten Sumbawa pada tahun 2015.Data kualitatif dan kuantitatif dikumpulkan menggunakan metode FGD, wawancara mendalam, dan observasi lapangan.Studi ini menunjukkan bahwa ada dua system pemeliharaan sapi di Sumbawa yang memberikan produktivitas dan pendapatan berbeda bagi petani.System tersebut adalah system 'lar" ekstensif di daerah padangan umum dan pribadi bisanya untuk tujuan pembiakan, dan system potong - dan - bawa pakan yang intensif umumnya untuk tujuan penggemukan menggunakan pakan lamtoro. Kelebihan kapasitas telah menjadi permasalahan utama pada system lar yang mengakibatkan produktivitas rendah. Akantetapi, tidak banyak yang telah dilakukan oleh petani untuk mengatasinya karena mereka beranggapan hal tersebut bukanlah sebuah masalah. Di sisi lain, ada potensi yang besar untuk mengatasi masalah tersebut dengan memanfaatkan sisa tanaman jagung yang tersedia melimpah setiap tahun. Sementara itu, system penggemukan yang intensif menggunakan pakan lamtoro telah memberikan pendapatan yang signifikan bagi petani (sekitar Rp. 500.000/ekor/bulan). Tulisan ini menyimpulkan bahwa secara sosial budaya, system lar memiliki peluang untuk pengembangan sapi di Sumbawa. Akan tetapi tantangan utamanya adalah mencukupi pakan yang berkualitas serta penyadaran petani untuk merubah perilaku dalam penyediaan pakan bagi ternaknya.
\end{abstract}

Kata Kunci: Sistem Lar, sisa tanaman, penyimpanan pakan, perubahan praktik, peningkatan manajemen 


\title{
CATTLE FARMING SYSTEMS IN ARID SUMBAWA: OPPORTUNITIES AND BARRIERS TO IMPROVE PRODUCTIVTY AND FARMERS INCOME
}

\begin{abstract}
Sumbawa Island is one of the cattle sources in Indonesia while integrated croplivestock system is commonly practiced as source of income for majority farmers. Low cattle productivity herehas been documented in a number of studies. This paper aims to explore opportunities and challenges to improve cattle productivity in dry Sumbawa by considering the various existing rearing system. A case study research was conducted in Sumbawa District in 2015. Quantitative and qualitative data were collected using FGD, in-depth interview and observation methods. The study showed that there are three cattle rearing systems in Sumbawa that provide varying productivity and income for farmers. They are extensive "lar" (grazing land) system both in communal and private areas, usually for breeding, and intensive cut-and-carry system based on Leucaena commonly for fattening. Over capacity has been the main issue in the lar system causing low productivity. Yet, little has been done as farmers still perceive it as not a problem. Contrastingly, there is a potency to improve the problem by utilizing crop residue (maize Stover) that are available abundantly every year. Meanwhile, intensive fattening system has provided significant income for farmers (around Rp. 500.000/head/month). This paper concludes that socio-culturally lar has a potency for cattle development in Sumbawa yet providing quality and sufficient feed and raising farmer awareness to change practices has been the main challenges.
\end{abstract}

Keywords: Lar system, crop residue, feed storage, practice changes, improved management

\section{PENDAHULUAN}

Provinsi Nusa Tenggara Barat terdiri atas Pulu Lombok dan Sumbawa yang telah ditetapkan sebagai salah satu sumber sapi nasional di Indonesia.Luas Pulau Sumbawa sekitar tiga kali luas Pulau Lombok dan memiliki 55\% populasi sapi NTB, umumnya sapi Bali.sementara jumlah penduduk di ini hanya sepertiga dari jumlah penduduk Pulau Lombok. Hal ini menunjukkan bahwa ruang untuk pengembangan sapi di Pulau Sumbawa jauh lebih besar dibandingkan di Lombok.Akan tetapi Sumbawa didominasi oleh daerah kering dengan hanya rata-rata empat bulan hujan setiap tahun. Karena itu masyarakat disini menerapkan system

https://ojs.unud.ac.id/index.php/soca integrasi tanaman pangan - ternak dengan sapi sebagai ternak utama sebagai sumber pendapatan.

Walaupun sapi memegang peranan penting mendukung perekonomian petani, namun produktivitas sapi Bali di Nusa Tenggara termasuk Pulau Sumbawa selama ini masih rendah karena system pemeliharaan yang intensif dengan mengandalkan alam sebagai sumber pakan (Wirdahayati and Bamualim, 1990 cited in Mastika, 2002; Bamualim and Wirdahayati, 2002; Talib et al., 2002; Dahlanuddin et al., 2009). Kekurangan pakan terutama pada musim kemarau merupakan permasalahan klasik.Sapi umumnya dilepaskan berkeliaran di tempat-tempat penggembalaan dengan kualitas hijauan pakan rendah

https://doi.org/10.24843/SOCA.2019.v13.i02.p01 
dengan kondisi yang lebih buruk pada musim kering. Akibatnya produktivitas sapi rendah yang terlihat dari tingkat pertumbuhan yang rendah, angka kematian anak tinggi dan jarak antar beranak yang panjang.Penelitian terdahulu (Wirdahayati, 1994) menyebutkan bahwa jarak antar beranak sapi Bali di Nusa Tenggara mencapai 14 sampai 18 bulan, sementara Sumbung, et al. (1978) melapokan rata-rata jarak antar beranak sapi Bali di Sulawesi Selatan adalah 11,1 bulan. Sementara itu, tingkat kematian anak sapi di Nusa Tenggara Barat tercatat mencapai 10,8\% (Wirdahayati, 1994), jauh lebih tinggi dibandingkan tingkat kematian anak sapi di Kalimantan Timur yang tercatat sebanyak 3,9\% (Solichin dan Sandhi, 1990).

Di sisi lain, Sumbawa memiliki sumber pakan potensial yang selama ini masih kurang dimanfaatkan yaitu sisa tanaman jagung. Sumbawa juga telah ditetapkan sebagai salah satu lumping jagung nasional. Pemanfaatan sisa tanaman jagung sebagai sumber pakan semestinya telah dapat mengatasi masalah kekurangan pakan dan meningkatkaan produktivitas sapi. Hanya saja, hal tersebut belum terjadi. Banyak petani masih membakar biomas jagungnya padahal mereka juga memiliki sapi yang kelaparan. Walaupun telah terdapat penelitian terdahulu tentang integrasi sapi jagung di Pulau Sumbawa seperti dalam tulisan Erawati dan Hipi (2011), namun penelitian tersebut tidak melihat aspek social dan system pemeliharaan sapi yang ada khususnya pada konteks Pulau Sumbawa. Karena itu tulisan in bertujuan untuk memberikan pemahaman berbagai system pemeliharaan sapi di Pulau Sumbawa yang kering dan mengeksplore peluang serta tantangan untuk meningkatkan produktivitas ternak sapi di sana sebagai sebuah rekomendasi bagi kegiatan-kegiatan penelitian dan pengembangan selanjutnya.Pentingnya kajian ini adalah memberikan perspektif strategi peningkatan produktivitas sapi pada kantung-kantung ternakterutama di wilayah Timur Indonesia yang didominasi oleh lahan kering, dengan memanfaatkan limbah tanamaan pangan yang tersedia melimpah di daerah tersebut. Hal yang tidak kalah pentingnya adalah memberikan rekomendasi desain dan proses pengkajian untuk merubah cara pandang dan pola pikirpetani untuk peningkatan produktivitas peternakan sapi dengan penerapan inovasi.

\section{METODOLOGI PENELITIAN}

Sebuah penelitian studi kasus (Yin, 2003) telah dilaksanakan pada tahun 2015 di Kabupaten Sumbawa sebagai bagian dari penelitian kerjasama antara Balai Pengkajian Teknologi Pertanian Nusa Tenggara Barat denganthe Australian Centre for Agricultural Research berjudul "Pengembangan system penggemukan sapi berbasis pakan legume pohon di Indonesia bagian Timur" dari tahun 2010 - 2015. Pengumpulan data tambahan dilakukan pada tahun 2017untuk pemutakhiran informasi. Kabupaten Sumbawa dipilih sebagai lokasi studi karena mewakili kondisi Pulau Sumbawa dan memegang 37\% populasi sapi provinsi NTB. Study kasus dilaksanakan di Kecamatan Rhee, Moyo Hulu, Moyo Hilir, Lopok dan Labngka. Responden terdiri dari petani, petugas kesehatan hewan, 
inseminator dan penyuluh. Data kualitatif dan kuantitatif dikumpulkan menggunakan metode FGD, wawancara mendalam, dan observasi lapangan. Data dianalisis secara thematic untuk dipresentasikan lebih lanjut secara deskriptif.

\section{HASIL DAN PEMBAHASAN}

\section{Kondisi Agro-Ecology dan Sistem Peternakan Sapi di Sumbawa}

Secara agro-ecology lokasilokasi penelitian identik dengan gambaran umum Pulau Sumbawa dengan topografi yang berbukit dan kering dengan bulan-bulan kering yang panjang (6-8 bulan). Karena itu usaha pertanian didominasi dengan komoditas-komoditas toleran kering dan berumur tidak terlalu panjang seperti jagung, kacang tanah, dan kacang hijau. Karena lahan pertanian sebagian besar merupakan lahan tadah hujan dengan kepemilikan lahan sekitar 1,5-2 ha/keluarga, padi hanya ditanam di daerah teririgasi di sebagian Moyo Hulu, Moyo Hilir dan Lopok. Kondisi yang kering ini telah mendorong petani untuk menerapkan system usaha tani integrasi tanaman pakan -ternak denngan sapi Bali sebagai ternak yang paling umum diusahakan. Sapi Bali telah dikenal sebagai ternak yang toleran kekeringan dengan kemampuannya untuk mengubah pakan berkualitas rendah menjadi produksi dan reproduksi. Karena itu, sapi memegang peranan penting sebagai tabungan dan buffer ekonomi rumah tangga petani.sebagai tabungan, sapi dianggap sebagai kumulasi aset yang akan dijual ketika keluarga membutuhkan dana dalam jumlah yang besar seperti untuk membuat rumah, sekolah anak, dan acara adat. Semetara sebagai buffer ekonomi, sapi akan dijual saat usaha tanaman pangan mengalami gagal panen.

Mayoritas usaha ternak sapi di Kabupaten Sumbawa dalah untuk tujuan pembiakan dengan rata-rata kepemilikan sapi sekitar 8-10 ekor per keluarga, yang mana angka ini dapat bervariasi dari puluhan hingga ratusan ekor. Dalam kawanan sapi tersebut tidak ada pemisahan antara indukan, pejantan ataupun anak. Karena itu, kawin dalam keluarga (inbreeding) umum terjadi karena kelangkaan pejantan. Petani tidak melakukan seleksi pejantan dan tidak jarang mengandalkan pejantan orang lain untuk mengawini indukannya. Pejantan yang besar biasanya dijual cepat untuk pemenuhan kebutuhan keluarga dan untuk biaya tani. Akibatnya pejantan yang tersisa untuk mengawini bukanlah yang terbaik sehingga bisa diperkirakan bahwa keturunannya akaan memiliki kualitas genetic yang rendah pula. Sebenarnya fenomena ini telah disadari oleh petani yang diwawancarai, namun hampir tidak ada dari mereka yang telah melakukan usaha signifikan mengatasi permasalahan tersebut. 


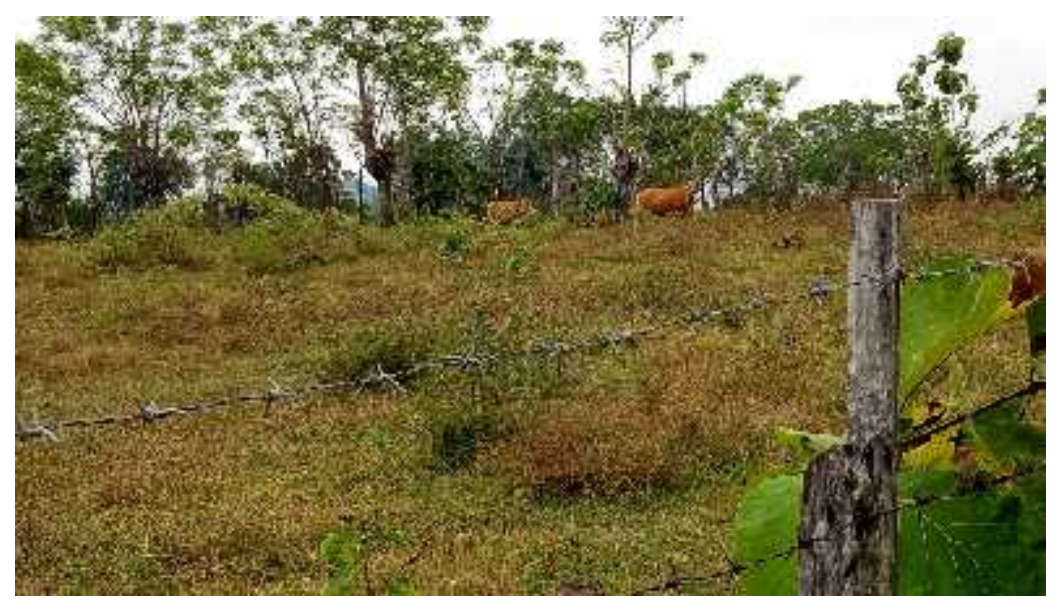

Gambar 1. Ternak di dalam Lar pribadi selama musim panen

Sapi umumnya dipelihara
secara tradisional degan sistem
intensive hingga semi-intensif. Untuk
system semi-intensif, selama musim
tanam (Desember - Mei), sapi
dipelihara di dalam lahan yang
dipagari yang disebut lardan
merumput di sana karena pada musim ini sapi yang berkeliaran dan merusak tanaman pangan akan didenda pemiliknya senilai panen tanaman yang dirusak. Lar dapat bersifat milik pribadi atau milik umum. Lar pribadi biasanya hanya digunakan sebagai tempat menampung sapi oleh petani saat musim tanam. Namun pada lar umum, banyak juga petani yang melepas sapinya di lar sepanjang tahun dan hanya datang untuk melihat kondisi sapi secara berkala. Lar ini biasannya berada di lerenglereng bukit dan area yang tidak digunakan sebagai lahan pertanian. Legume pohon seperti Gliricidia dan lamtoro banyak tumbuh dijadikan sebagai pagar kandang namun hampir tidak tersentuh oleh sapidan tidak dimakan. Setelah panen tanaman pangan selesai, petani membawa sapisapi mereka ke lahan pertanian untuk memakan sisa tanaman pangan seperti batang jagung dan juga ke pinggir jalan dan lahan umum untuk merumput di sana.

Permasalahan utama peternakan sapi dengan sistem semi intensif dan ekstensif di Kabupaten Sumbawa adalah ketimpangan yang sangat besar antara ketersediaan pakan dan jumlah populasi sapi yang menyebabkan rendahnya skor kondisi tubuh, produktivitas dan reproduksi. Sebagai gambaran, ada 1 sampai 2 lar umum di wilayah Desa Moyo Hulu dengan luasan sekitar 50 Ha. Lar tersebut harus menampung lebih dari 2.000 ekor sapi. Di wilayah lain di Lopok, terdapat lar dengan ukuran yang lebih besar yang dinamakan lar Badi, berukuran sekitar 600 Ha. Lar ini digunakan oleh 396 petani dari empat desa yaitu Langam, Lopok Bru, Lopok dan Hijrah dengan jumlah ternak sekitar 17.000. Dari seluruh luas lar Badi ini, hanya sekitar $350 \mathrm{Ha}$ yang bisa dimanfaatkan sebagai pada penggembalaan karena invasi Chromolaina yang menutupi hampir separuh dari lar Badi ini. Karena letak lar Badi yang jauh dari pemukiman dan kondisi jalan yang rusak berat terutama pada musim hujan, petani biasanya mengontrol sapinya sekali sebulan. Dengan kondisi ini, petani sering kehilangan pedet dan sapi 
karena kematian dan pencurian. Dari wawancara dengan petugas dinas kecamatan terungkap bahwa petani sudah merasa beruntung bila mendapatkan pedet hidup separuh dari jumlah indukan yang dimilikinya. Bahkan petani kadang tidak mendapatkan pedet sama sekali karena mati atau hilang. Tingginya angka kematian pedet di Kabupaten Sumbawa ini juga konsisten dengan studi terdahulu yang dilakukan oleh Bamualim (2011) dan Panjaitan (2017).

Gambaran dari Moyo Hulu dan Lopok ini menunjukkan bahwa lar di Kabupaten Sumbawa telah mengalami over grazing dan kelebihan kapasitas tampungan dengan jumlah 40-49 ekor/Ha. Padahal untuk daerah tropis dengan kualitas hijauan rumput alam yang menurun dengan cepat pada musim kemarau, kapasitas tampungan yang disarankan seharusnya tidak lebih dari 0,5-1,5 ekor/Ha (O'Reagain and Scanlan, 2013). Hal ini untuk mendukung regenerasi dan ketersediaan pakan yang akan berhubungan langsung dengan kondisi tubuh sapi.

Dengan kondisi lar di Kabupaten Sumbawa terlihat jelas melebihi kapasitas daya tampung dan mengakibatkan rendahnya produktivitas sapi, beberapa inisiatif perbaikan telah dilakukan oleh pemerintah daerah melalui dinas terkait. Sebagai contoh pembangunan penampungan air dan pengembangan penanaman rumput berkualitas tinggi. Akan tetapi fasilitas penampungan air ini tidak bisa dipelihara karena kurangnya kesadaran para petani pengguna yang belum terorganisir dengan baik dan faktor kepemimpinan. Sementara pengembangan penanaman rumput juga tidak bisa berlanjut karena selalu dirusak oleh ternak yang kelaparan walaupun sudah dipagari. Karena itu terlihat dari hasil studi ini bahwa kelebihan daya tampung padang penggembalaan, pengetahuan petani yang terbatas untuk manajemen pakan dan pemelihraan sapi serta lemahnya kelembagaan organisasi petani telah berkontribusi terhadap rendahnya performa peternakan sapi di Kabupaten Sumbawa. Hal ini terlihat dari skor kondisi tubuh yang rendah terutama di musim kemarau, pertumbuhan tubuh yang rendah dan tingkat kematian pedet yang tinggi.

Performa peternakan sapi yang kurang menggembirakan di Kabupaten Sumbawa dengan sistem semi-intensif dan ekstensif ini juga diperburuk dengan kondisi bahwa sebagian besar sapi indukan melahirkan pada bulan Juni - Juli, yang mana merupakan musim kemarau. Bahkan tiga bulan berikutnya yang merupakan masa kritis untuk pertumbuhan pedet juga merupakan bulan-bulan yang lebih kering. Hal ini akan menimbulkan efek domino negative untuk tingkat pedet yang bertahan hidup. Indukan menyusui dengan pakan berkualitas rendah pada musim kemarau akan menghasilkan air susu dengan jumlah dan kualitas rendah juga. Dengan kualitas air susu seperti ini, pedet pun akan tumbuh lambat, cenderung lemah dan rentan terhadap serangan penyakit. Bila jumlah pedet yang bertahan hidup sedikit, maka usaha peternakan sapi tersebut juga menjadi kurang menguntungkan bagi petani karena hasil yang paling diharapkan adalah dari penjualan pedet yang biasanya dijual tahun depan setelah adiknya lahir dengan harga sekitar Rp. 7 juta/ekor. Oleh karena ini, 
perbaikan secara menyeluruh dengan melihat sistem peternakan yang ada sangat dibutuhkan. Hal ini tentu saja harus melibatkan seluruh pihak terkait di Kabupaten Sumbawa.

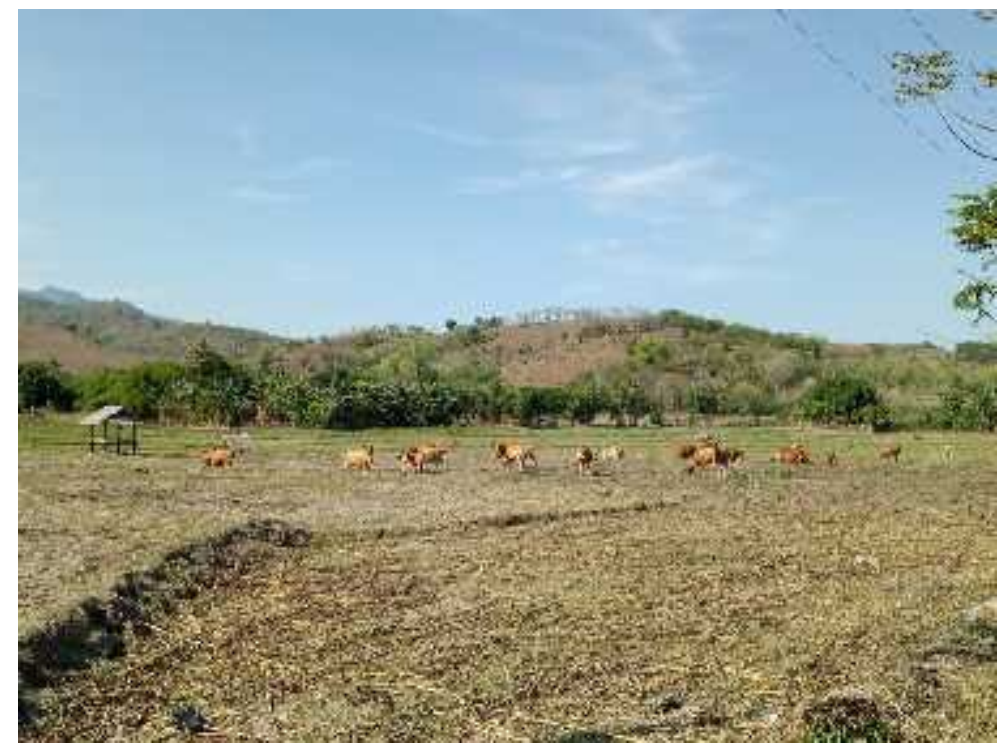

Gambar 1. Sapi merumput di lahan bekas pertanaman jagung setelah musim panen dengan ketersediaan pakan yang rendah secara jumlah dan mutu.

Sementara itu, di beberapa tempat terbatas di Kabupaten Sumbawa seperti di Rhee dan Labangka, petani transmigran dari Bali dan Lombok telah melakukan usaha penggemukan sapi menggunakan pakan lamtoro. Sapisapi penggemukan ini dipelihara secara intensif dikandangkan. Dibandingkan petani lokal Sumbawa, petani transmigran ini lebih maju dalam hal orientasi peternakan sapi karena telah menjadikan ternak sapi sebagai usaha bisnis yang mendatangkan penghasilan berkala. Usaha penggemukan sapi ini biasanya dilakukan dalam jangka waktu enam bulan per periode penggemukan dengan pendapatan sekitar Rp. 500.000/ekor/bulan. Rata-rata jumlah yang digemukkan sekitar 4-5 ekor per keluarga. Bahkan ada seorang petani wanita di Rhee yang biasa memelihara hingga 20 ekor sapi penggemukan dalam satu periode penggemukan.

\section{Peluang Peningkatan Produktivitas Sapi di Sumbawa}

Peternakan sapi di Sumbawa telah menunjukkan tingkat produktivitas yang rendah dimana kekurangan pakan merupakan salah satu faktor penyebab klasik terutam pada musim kemarau. Pada saat yang bersamaan wilayah ini dikarunia sumber pakan melimpah berupa sisa tanaman pangan yang belum banyak dimanfaatkan. Sisa tanaman pangan yang paling banyak tersedia adalah berangkasan jagung, yaitu bagian aats tanaman jagung yang bisanya dipotong beberapa hari sebelum panen. Akan tetapi, potensi pakan ini banyak diabaikan oleh petani karena kurangnya pengetahuan mereka akan berangkasan jagung sebagai pakan sapi, keterbatasan tenaga kerja untuk mengumpulkan berangkasan jagung 
dan tidak adanya tempat penyimpanan.

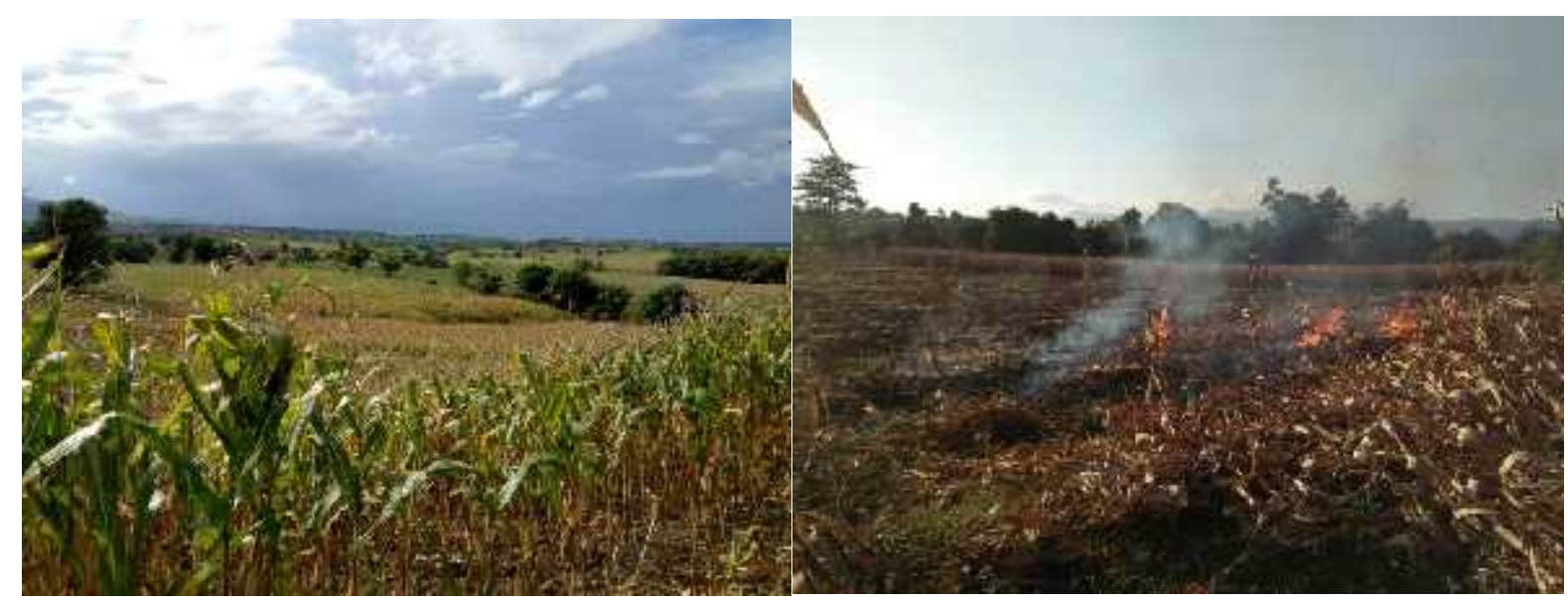

Gambar 2. Tanaman jagung di Labangka, salah satu pusat penghasil jagung di Sumbawa, potensi besar sebagai sumber pakan namun belum dimanfaatkan karena petani membakarnya untuk tanaman pangan berikutnya.

Berangkasan jagung merupakan sumber pakan potensial dengan produktivitas tinggi. Satu hektar lahan yang ditanami jagung dapat menghasilkan 3-4 ton berangkasan kering dengan kadar air 20\% (Erawati dan Hipi, 2011). Sementara itu luas lahan di Kabupaten Sumbawa yang ditanami jagung mencapai 43.043 ha (BPS, 2015). Hal ini berarti berangkasan jagung yang dihasilkan setiap tahun sejumlah minimal 129.000 ton belum dimanfaatkaan sebagai sumber pakan. Dengan mengacu pada kebutuhan asupan bahan kering sapi sekitar $1-3 \%$ berat badan dan kandungan protein sekitar $12 \%$ untuk induk (Lalman dan Richards; Bakrie, 1996) dan kandungan protein kasar berangkasan jagung sejumlah 7,4\% (Subandi dan Zubachtirodin, 2004) maka sekitar dua per tiga kebutuhan pakan sapi dapat dipenuhi dari berangkasan jagung. Sementara sepertiganya lagi dapat diberikan dari legume pohon seperti lamtoro yang banyak tersedia di lingkungan sekitar dengan kandungan protein kasar di atas 20\% (Nhan, 1998; Dahlanudin, 2009; Zayed et al, 2014). Dengan kata lain, berangkasan jagung yang dihasilkan di Kabupaten Sumbawa dengan suplemen pakan lamtoro dapat mendukung kehidupan sekitar 98.000 ekor sapi sepanjang tahun dengan asumsi berat badan rata-rata 200 kg. Sebuah study menunjukkan bahwa pemberian pakan lamtoro akan menaikkan berat badan sapi Bali sekitar 0,6 kg/hari (Panjaitan et al., 2014) dibandingkan dengan kenaikan $0,05-0,7 \mathrm{~kg} /$ hariselama musim kemarau dan 0,2 - 0,4 kg/haripada musim hujan bila hanya diberikan rumput alam (Bahar dan Rakhmat, 2003, cited in Chamdi, 2005). Angkaangka ini menujukkan bahwa pemanfaatan berangkasan jagung sebagai pakan dapat mendukung kehidupan sekitar $40 \%$ populasi sapidi Kabupaten Sumbawa yang tercatat sejumlah 228.042 ekor (BPS, 2015). 
Pemanfaatan sisa pkan seperti berangkasan jagung memerlukan tampat penyimpanan yang baik untuk memberikan manfaat yang optimal bagi sapi. Kebanyakan petani Sumbawa tidak menyimpan pakan karena masih mengandalkan alam sebagai sumber pakan. Hal ini mengindikasikan bahwa performa sapi yang masih rendah akibat kekurangan pakan terutama pada musim kemarau di Kabupaten Sumbawa memiliki hubungan yang erat dengan perilaku dan kebiasaan petani yang tidak menyimpan pakan. Alasan yang sering diungkapkan oleh petani antara lain kekurangan sumberdaya untuk membuat tempat penyimpanan pakan dan kurangnya pengetahuan tentang tehnik-tehnik penyimpanan pakan. Akan tetapi, sejumlah kecil petani di beberapa tempat wilayah Kabupaten Sumbawa sudah mempraktekkan penyimpanan pakan dengan kearifan lokal yang disebut "pakan sia". Pakan sia ini sangat mudah untuk dicontoh bago petani di tempat lain. Prinsip utama pakan sia ini adalah penyimpanan pakan dekat dengan lokasi penggembalaan dan pakan mudah diakses oleh sapi. Peran pakan sia ini tampak dominan terutama pada musim tanam dimana sapi-sapi tidak diizinkan untuk berkeliaran merumput.

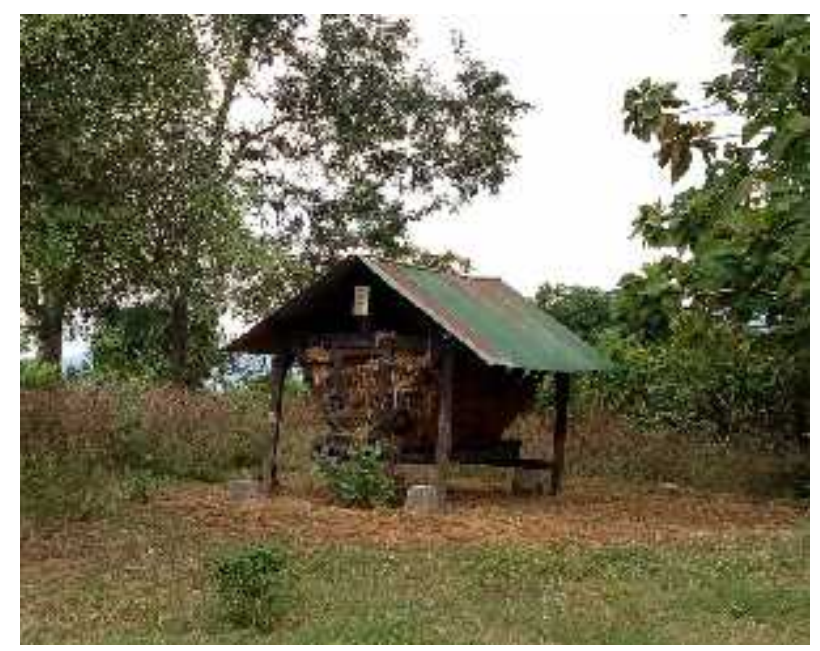

Gambar 3. Pakan sia, fasilitas penyimpanan pakan yang dikembangkan oleh masyarakat lokal Sumbawa.

\section{Kendala untuk Pengembangan Peternakan Sapi}

Dengan melihat produksi jagung di Kabupaten Sumbawa dan potensi berangkasan jagung sebagai seumber pakan sapi, masalah kekurangan pakan di daerah ini seharusnya tidak terjadi. Akan tetapi kenyataan menunjukkan kondisi yang sebaliknya. Petani masih membakar sisa tanaman jagung sementara sejumlah besar sapi berkeliaran mencari makan dnegan kondisi tubuh yang kurus. Studi ini mengidentifikasi beberapa hambatan untuk peningkatan produktifitas sapi di Kabupaten Sumbawa yang meliputi hambatan fisik dan sosial-ekonomi, antara lain:

\section{Rendahnya kesadaran dan pengetahuan \\ Sebagian besar petani Sumbawa masih mengandalkan alam sebagai sumber pakan terutamaa}


rumput alam. Ada persepsi umum diantara mereka bahwa alam akan mampu menghidupi ternak-ternak mereka. Karena itu menanam dan menyimpan pakan untuk sapi tidak pernah terbersit dalam pikiran mereka. Selain itu, pengetahuan tentang sumber-sumber pakan, qualitas dan manajemen penyediaan pakan juga masih rendah. Hal ini terbukti dari masih belum dimanfaatkannya legume pohon seperti gamal dan lamtoro yang banyak tersedia di sekitar lingkungan sebagai pakan sapi. Petugas dinas yang diwawancarai mengungkapkan selama sapi nampak memakan sesuatu di tanah, petani tidak terlalu memikirkan kulaitasnya. Seringkali terlihat sapi merumput di padangan yang hanya berisi batang jagung kering yang sudah mulai menghitam namun pemilik sapi yang kadang berada tak jauh dari sapi tampak tidak melakukan usaha apapun untuk mencukupi kebutuhan pakan sapi tersebut.

\section{Usaha peternakan sapi tidak berorientasi bisnis}

Hampir semua peternak di lokasi studi menganggap peternakan spai mereka sebagai kegiatan sampingan. Hanya sebagian kecil petani yang sudah menganggapnya sebagai usaha utama terutama petani yang sudah menjalankan usaha penggemukan sapi. Oleh karena itu sebagiaan besar petani hampir tidak pernah melakukan perhitugan akan tenaga kerja, waktu dan usaha yang dikeluarkan untuk memelihara sapi dibandingkan dengan produktivitas sapid an penghasilan yang didapatan. Biasanya sapi hanya dihitung jumlah ekornya tanpa terlalu memperhatikan kondisi pertumbuhan badannya.Hal ini juga diperburuk dengan sistem penjualan sapi di Sumbawa yang hanya berdasarkan perkiraan "cawangan", bukan berdasarkan harga per kilogram berat badan.Ada ungkapan yang terkenal di kalangan petani Sumbawa bahwa selama petani masih bisa menghitung ekor sapi (sapi masih hidup), maka sudah cukup membuat petani senang.Oleh karena itu, hampir tidak ada usaha yang tampak dilakukan oleh petani untuk meningkatkan produktivitas peternakan sapinya dengan memperbaiki manajemen pemberian pakan atau kesehatan ternaknya.

\section{Konsekuensi biaya tambahan dan gaya hidup santai}

Meningkatkan produktivitas sapi melalui perbaikan manajemen seperti perbaikan pakan dan cara peberian pakan, seringkali juga berarti tambahan biaya dan usaha bagi petani. Seringkali petani melihat berbaikan ini sebagai kendala perbaikan manajemen karena tidak adanya perhitungan bisnis. Akibatnya petani enggan untuk melakukan perubahan. Sebagai contoh, penanaman dan penyimpanan pakanakan membutuhkan biaya. Seringkali biaya tambahan inilah yang menjadi focus petani dibandingkan dengan keuntungan dan pendapatan yang akan didapatkan dengan melakukan perubahan dan perbaikan manejemen tersebut. Keadaan ini diperburuk dengan kebiasaan petani Sumbawa yang umumnya membiarkan sapinya menacri makan sendiri di padang penggembalaan. Karena itu, mengangkut dan menyediakan pakan untuk sapi dianggap sebagai pekerjaan yang diperbudak oleh sapi yang mana seharusnya pemilik sapilah yang dilayani oleh sapi. Karena itu banyak petani yang lebih memilih duduk 
sambil mengamati dan menghitung sapinya yang kurus dibandingkan berusaha bangkit untuk mencari dan menyediakan pakan agar kondisi tubuh sapinya lebih baik.

\section{KESIMPULAN}

Ada dua sistem pemeliharaan sapi di Kabupaten Sumbawa yang memberikan produktivitas dan pendapatan yang berbeda untuk petani. Sistem pertama adalah sistem larekstensif dan semi-intensif baik di lahan pribadi maupun lar umum dimana sapi merumput di padangan dan biasanya untuk sapi pembiakan. Sementara sistem kedua adalah sistem intensif di kandang yang biasanya untuk sapi penggemukan menggunakan lamtoro dengan manajemen pakan sistem potong-danbawakan. Kelebihan kapasitas telah menjadi permasalahan utama pada sistem lar yang mengakibatkan produktivitas sapi yang rendah ditandai dengan rendahnya tingkat pertumbuhan dan angka kematian pedet yang tinggi. Akan tetapi tidak banyak yang telah dilakuan oleh petani untuk mengatasi amsalah ini karena anggapan mereka bahwa hal tersebut buanlah sebuah masalah. Di lain sisi, Kabupaten Sumbawa memiliki potensi besar untk perbaikan peternakan sapi dengan memanfaatkan sisa tanaman jagung (berangkasa) yang tersedi melimpah setiap tahun namun belum dimanfaatkan. Sementara itu, dengan sistem pemelihraan yang intensif untuk penggemukan sapi menggunakan pakan lamtoro telah memberikan pendapatan signifikan kepada petani sejumlah Rp. $500.000 /$ ekor/bulan.
Secara sosial budaya, Kabupaten Sumbawa dengan sistem pemelihraan lar memiliki potensi untuk penngembangan peternakan sapi mengingat luas wilayahnya dan ketersediaan sisa tanaman pangan yang bisa dimanfaatkan sebagai pakan yaitu berangkasan jagung. Akan tetapi kendala utama yang dihadapi adalah peningkatan kesadaran petani untuk merubah cara beternak dan cara penyediaan pakan. Sebagian besar petani masih beranggapan bahwa beternak sapi hanyalaah aktivitas sampingan dan mengandalkan alam sebagai sumber pakan. Petani masih enggan untuk mengeluarkan biaya dan tenaga tambahan untuk memperbaiki sistem produksi ternak sapinya. Karena itu diperlukan sistem inovasi dan penyuluhan yang dapat mengakomodir sistem beternak sapi yang sudah ada dan juga memperhatikan kondisi sosial dan ekonomi masyarakat di Sumbawa.

\section{DAFTAR PUSTAKA}

Bakrie, B. 1996. Feeding Management of Ruminant Livestock InIndonesia. In: Ruminant nutrition and production in the tropics and subtropics. Editors: Bakrie, B., Hogan, J., Liang, JB., Tareque, AMM., Upadhyay, RC. Australian Centre for International Agricultural Research. Canberra.

Bamualim A, Wirdahayati RB. 2002. Nutrition and management strategies to improve Bali cattle productivity in Nusa Tenggara. Proceedings of the ACIAR workshop Strategies to improve Bali cattle in Indonesia, Bali, Indonesia, 4-7 February 2002. p. 17-22. 
Bamualim, AM. 2011. Pengembangan Teknologi Pakan Sapi Potong Di Daerah Semi-Arid Nusa Tenggara.Pengembangan Inovasi Pertanian. 4(3): 175188.

BPS NTB. 2017. NTB dalam angka. https://ntb.bps.go.id/dynamic table/2017/04/02/97/luaspanen-rata---rata-produksidan-produksi-jagung-menurutkabupaten-kota-2012.html.

Chamdi, AN. 2005. Karakteristik Sumberdaya Genetik Ternak Sapi Bali (Bos-Bibos Banteng) Dan Alternative Pola Konservasinya.Biodiversitas.6(1 ): $70-75$.

Dahlanuddin, Muzani A, SutaryonoYA, McDonaldC. 2009. Strategi Peningkatan Produktivitas Sapi Bali Pada Sistem Kandang Kompleks: Pengalaman Di Lombok Tengah, NTB. Paper presented at the Pengembangan Sapi Bali Berkelanjutan dalam Sistem Peternakan Rakyat, Mataram.

ErawatiTR, HipiA. 2011. Potensi Beberapa Varietas Jagung Dan Limbahnya Sebagai Pakan Ternak Dalam Mendukung Pengembangan Sejuta Sapi di Nusa Tenggara Barat. Prosiding Seminar Nasional Teknologi Peternakan dan Veteriner. Bogor.

Lalman D, Richards C. Nutrient Requirements of Beef Cattle. Department of Animal Science. Oklahoma Cooperative Extension Service. Division of Agricultural Sciences and
Natural Resources.Oklahoma State University.

Mastika IM. 2002. Feeding strategies to improve the production performance and meat quality of Bali cattle (Bos sondaicus). Proceedings of the ACIAR workshop Strategies to improve Bali cattle in Indonesia, Bali, Indonesia, 4-7 February 2002. p. 10-13.

Nhan, NTH. 1998. Effect of Sesbania glandiflora, Leucaena leuocephala, Hibiscus rosasinensis and Ceiba pentandra on Intake, Digestion and Rumen Environment of Growing Goats. Livestock research for Rural Development. 10(3).

O'Reagain PJ, Scanlan JC. 2013. Sustainable Management for Rangeland in A Variable Climate: Evidence And Insights From Northern Australia. Animal. 7(1):68 - 78 . Doi.10.1017/S1751731111002 $62 \mathrm{X}$.

Panjaitan, T. 2017. Pakan Tambahan Meningkatkaan Pertumbuhan Pedet Prasapi. Infotek. Vol.1: 117. BPTP NTB.

Panjaitan T, Fauzan M, Dahlanuddin, HallidayMJ, SheltonHM. 2014.Growth of Bali Bulls Fattened with Leucaena leucocephala in Sumbawa, eastern Indonesia.Tropical Grasslands - $\quad$ Forrajes Tropicales.2: 116-118.

Solichin $\mathrm{H}$ dan Sandhi AA, 1990.Perkembangan Sapi Bali Dewasa di Kalimantan 
Timur.Prosiding Seminar Nasional Sapi Bali. 20-22 September, 1990. Denpasar, Bali. p.F-28.

Subandi, Zubachtirodin. 2004. Prospek Pertanaman Jagung Dalam Poduksi Biomas Hijauan Pakan. Prosiding Pemberdayaan Petani Miskin di Lahan Marginal Melalui Inovasi teknologi Tepat Guna. Badan Litbang Pertanian, Jakarta. pp. $105-110$.

Sumbung FP, Batasoma JT, Ronda RB, Garantjang S. 1978. Performans Reproduksi Sapi Bali.Seminar Ruminansia, Pusat Penelitian dan Pengembangan Peternakan, Bogor.

Talib C, Entwistle K, Siregar A, Budiarti-Turner S, Lindsay D. 2002. Survey of population and production dynamics of Bali cattle and existing reeding programs
Indonesia.Proceedings of the ACIAR workshop Strategies to improve Bali cattle in Indonesia, Bali, Indonesia, 4-7 February 2002. p. 3-9.

Wirdahayati RB. 1994. Reproductive Characteristics and Productivity of Bali and Ongole Cattle in Nusa Tenggara, Indonesia. PhD Thesis.University of Queensland, Brsibane.

Yin RK. 2003. Case Study Research: Design and Methods.Third ed. Vol. 5. London: SAGE Publications.

Zayed MZ, Zaki MA, Ahmad FB, Ho W, Pang S. 2014. Comparison of Mimosine Content and Nutritive Values of Neolamarckia cadamba and Leucaena leucocephala with Medicago sativa as Forage Quality Index.International Journal of Scientific \& Technology Research. 3(8): 146-150. 